\title{
RESEARCH ON (DREAM) IN USTAD SHPOON (REFUGEE DREAM) POEM
}

\author{
Sayed Asghar Hashimi \\ Education Faculty's Teacher \\ Pashto Language and Literature Department \\ Sayed Jamaldin University, Afghanistan \\ E-mail: hashimi.saidasghar1@gmail.com \\ Sayed Ghani Ghani \\ Education Faculty's Teacher \\ Pashto Language and Literature Department \\ Nangarhar University, Afghanistan \\ E-mail: ghanisayedghani@gmail.com \\ Shafiqullah Rahmani \\ Education Faculty's Teacher \\ Pashto Language and Literature Department \\ Nangarhar University, Afghanistan \\ E-mail: ShafiqullahRahmani88@gmail.com
}

\begin{abstract}
This article is a research on the word "dream" in a poem by Ustad Shpoon, but in addition to the research on dream, it also talks about black color. For instance, the night is black (dark), you have a dream in the black (dark) night. The "black color" has been mentioned in this research as well. Good and bad dreams have been mentioned in the research on dreams and it has been clarified whether the "Refugee Dream" poem takes the side of goodness or badness. Another important thing about dreams is Symbolic and Simple dream. The poem that we are discussing here talks about simple and clear dream. This article researches dream in a poem of Saadudin Shpoon based on a theory. Verses of the same poem have been mentioned here and research on dream has been implemented in it psychologically. The goal of this research is writing an academic article and studying a poem according to psychology which will pave the way for other authors to research from two-dimensional perspectives. This is a library research which has used descriptive and explanatory methods. Materials have been collected from books and after analysis and interpretation, we have reached a conclusion. The achievements of this article are it recounts past memories of Shpoon through his poem. He notices black color while dreaming at night which is related to his past and manifests his problems. The value of this article is it contains new points about Shpoon which have never been studied before.
\end{abstract}

Keywords: Dream, Black, Color, Yung, Symbol.

\section{INTRODUCTION}

Ustad Shpoon is a good researcher and creator of literary works. His language skills and fiction literature in Pashto Literature is valuable. In addition to it, his poems are also worth mentioning. His poetic articles have balance and steadiness between his words of speech and meanings. 
There are several authors who ignore the said balance between meanings and words, but his poems are enriched with the mentioned balance between words and the meanings. Besides, his poems have so many social aspects. Researchers can research his creativities from new aspects. This article, that I have written, researches a poem of Ustad Shpoon in point of view of Carl Gustavo Yung's Theory.

(Shpoon is a well-known figure, author, Critic and researcher.) (Only one Shpoon, 2020) Saadudin Shpoon is a poet who has lived far away from his homeland.

There are many issues in the consciousness and consciousness of a human which sometimes take people to past life and these memories are felt while dreaming.

The Novelty of the Subject: Few articles have been written on Mr. Shpoon and the study of dream in his poems will probably be the first article. Literature has relationship with psychology and this article is its good example. As it is clear, the methods of a research needs new issues and to prove a hypothesis, understanding other knowledge is also important in addition to specialization which, in fact, can prove novelty.

Objectives of the Subject :Clarification of the need for researching on the word "Dream" in the poem (The Refugee Dream) From Psychological point of view and as we know dreams come at night and the night is dark and has black color. Therefore, research on dreams and the mention of black color are the also the objectives of this research.

Questions About the Subject :Is "Refugee Dream" related to the research on dream from the point of view of Yong or not?

Is the relation between the dreams and black color an important point in researching dreams?

\section{METHODS OF THE SUBJECT}

This research is a library research and descriptive and analytical methods have been used in it. Various works have been studied for the completion of the chosen research work. Subject related materials have been organized and arranged which have been mentioned in different parts of this article considering the reference rules and regulations. After explanation and clarification, we reached the conclusion. The opinion of every one was taken and along with the opinions of the author, the research ended.

\section{DISCUSSION}

Spoon is a powerful Pashto poet, researcher, creator and translator. His poems have many facets, one of which is to be studied in terms of psychological theory.

Says:

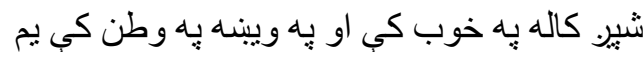

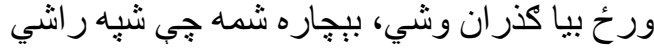

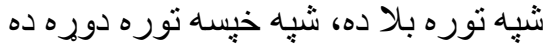

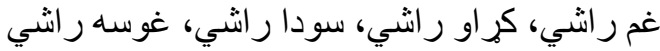

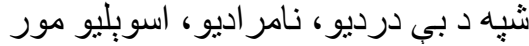

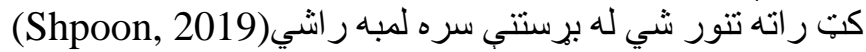

The concept of the poem: The poet dreams, during the dream he has been at home, village and country for six years. He is satisfied of the day, but when the night comes, his feeling of sadness increases. He can tolerate it during the day, but the poet becomes poor and loses everything at night. He calls night the black monster, considers it a symbol of fright and is angry with night. He compares night with sadness and when he falls asleep, the bed turns into a hot oven for him. 
He has bad dreams at night, which has a relationship with his past. He is in stranger's country, away from his homeland and misses his country and spends his day and night in immense sadness. One of the reasons is he has bad dreams about his country.

Due to revolution and different other problems, Ustad Saadudeen Shpoon like other scholars and poets emigrated and had to face a lot of problems. He grew old and week and got into the trouble of missing the past times. In his poetry, memories of home, village, friends, mother and childhood are seen. Therefore, he developed his nostalgic wishes based on internal aspirations which bothered him both while he was awake or in bed

In his poetry, the mention of black color is very common. My article is about researching on dreams in one of his poems. Dreams mostly come at black (dark) night therefore the three-sided relation of dream, night and black color is worth researching. The verses above also make a mention of dreams. When night comes, everything gets black which does not let the author sleep and bad dreams come to him due to various problems.

In the research on colors, psychology of colors discusses various colors and shows the effects of each color on humans and their souls.

(Since ancient times, the use of color has been common in Egypt, India and other places. Egyptians used colors in their ancient Egyptian temples which benefited the ego and soul of people. They also took the sick people to these places for treatment.

The mullahs of Egypt believed that colors save lives and that lives have no meaning without colors and they are the colors which have healing power and magic. In China and India (Chromo therapy) was very common. Even some scholars still believe that each external and internal human organ has an association with a certain type of color which activates that particular organ and unless the color is not seen or felt, the organ's activity decreases) (Zadran, 2010).

He says about the color black:

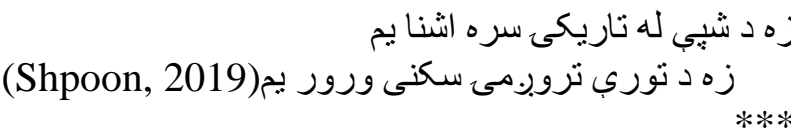

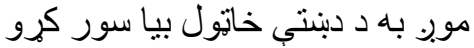

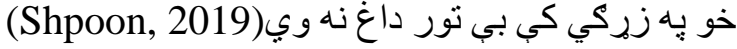

The concept of the quatrain: The poet says that he is familiar with dark (black) nights. The poet uses 'black night' to mean problems and troubles in his life. He adds that he is the full brother of black nights and darkness. The night dreams cause problems for him and he is made of these problems. The poet makes a mention of black color, night is black, dreams come at night and he therefore complains about the mentioned color.

Reading the poems and poetry of Mr. Shpoon, we get to know that he is very sad, he misses his country, sometimes he goes to his mother's lap and his mother moves her hands into his hair. He complains about revolution and killings, walks in the gardens of his village, on the fields and on the banks of the streams and misses his childhood.

(Black is the color of depression. A Pashto proverb also proves this, "My heart is black for him." Meaning that I hate him. Black color causes depression which is mainly due to the loss of psychological energy. Colors are used as symbols in poetry. Black color is also a symbol of death.

For example, red and green are the colors of happiness, while yellow, gray and black are boring and lifeless colors, which evoke sadness and depression) (Kargar, 2016).

Studies have shown that Norway is close to the North Pole, and Northern Norway has long nights in winter, where the depression percentage is higher from southern Norway because North Norway has longer nights than the nights South Norway has. 
The mention of black color in Shpoon's Poetry shows that he is very disappointed and sad. In addition, black means "no" and "white" means "yes". Black color belongs to negative intention and negativity while white belongs to positive intention and positivity.

Ustad Shpoon does not like night. He therefore does not like black color because bad dreams also come to him in black (dark) night. In his poem namely "Refugee Dream", he dreams about going to his house and village. He says:

$$
\begin{aligned}
& \text { خوب وينم عالمه كه يب خوك ر راكري معنا }
\end{aligned}
$$

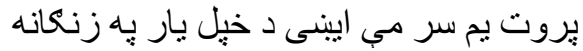

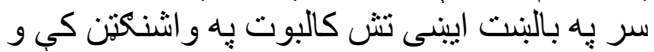

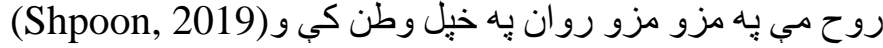

The concept of the above couplets. I dream and can I find someone to interpret it for me. I felt sleepy and put my head on the knee of my friend. In reality, it is night and my head is on the pillow and I am in Washington. I am away from my country and I am like a body which has no soul in it and is like an empty body. My soul was enjoying walking because I was in my homeland.

The poet dreams about his country and his dreams are the incidents and times lying in unconsciousness and social unconsciousness which bother him and take him to his past in this dreams.

In the above verses there is a mention of soul and body. The body is the frame which stops working at the time of sleeping. It is alive, but unable to work.

Sometimes it performs unconscious things while sleeping. It performs unconscious things during the sleeping time and sometimes, the stored things of social unconsciousness are seen in the dream. Sometimes a human has an intention to do something when he or she is awake, but cannot do it due to certain problems. Every human has wishes which cannot be fulfilled in the real life. There are also many issues and incidents that humans have experienced in their life and are seen in the dreams. The language of dream is a language of unconsciousness and appears in the form of symbols and colors.

$$
\begin{aligned}
& \text { دند د شمالي ته شوم انكور ميز ان و هلي }
\end{aligned}
$$

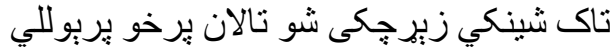

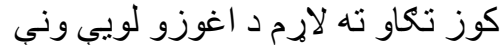

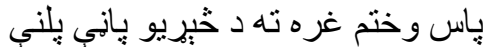

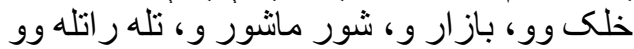

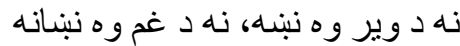

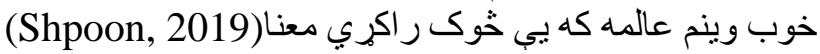

The concept of the poem: The poet says, I go my home and village, walk under the trees, visit people, and climb up the mountain. There are trees in the mountains which have beautiful weather. There is no fear, no sadness, only happiness everywhere. Oh, people, I dream! Is there anyone who can interpret my dream it for me?

The poet's dream shows that he goes to his past life in his dreams and his past is present in his inner world which sometimes shows it in his dreams due to external reactions.

There is an aspiration for the past in the poem above. Nostalgic problems can be noticed in the author. Therefore, he mentions his past time memories and aspires to have them, but cannot achieve them. He is away from his homeland and dreams about things which he does not have in reality when he is awake. These situations exist in the inner world of Ustad Shpoon which is sometimes shown by the certain problems, situations and external senses. He dreams about it when he falls asleep.

(Dreams are divided into two kinds: Positive (Good) dreams and Negative (bad) dreams. Personality of every human can be identified in his dreams. People who have bad 
characters and have committed evil things rather than good things, have bad dreams because their unconsciousness is full of such bad incidents.

To prove the points I mentioned above, Zoroastrian's Guide, which is considered important in the religion, states that every human should have nice words, deeds and thoughts. It means the thoughts of every human are associated with their deeds and activities and their words are associated with their thoughts and deeds. The thought, deed, character of every human being has an effect on each other) (Herawi, 2014). The unconsciousness of every human being has a relation with his/her thinking. When a human has a certain thinking, it is felt in his actions and words and stored in his unconsciousness. Furthermore, all his activities are associated with his thinking and his thinking manages his actions. His words also come to existence by his thought which becomes visible in his actions.

The dreams of human beings have a strong relationship with their thoughts, words, and actions. What one dreams is a result of his / her thoughts, actions and vision. Shpoon has good dreams which show that his past stored conditions were very good and represents his personality. In the end of the poem, he says:

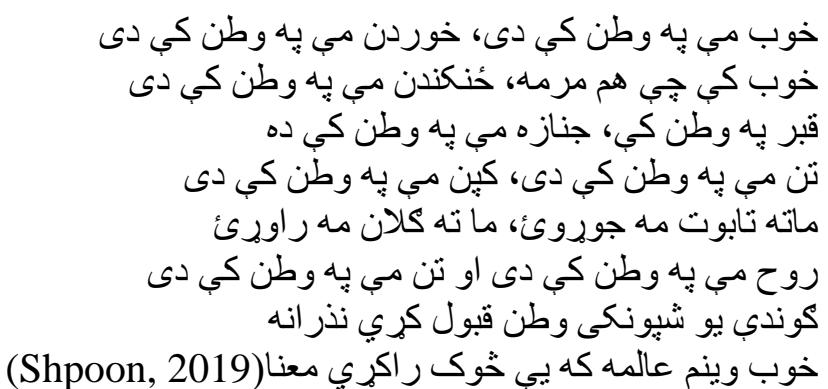

The poet says, When I go to bed, I sleep in my country, eat in my country. Sometimes I die and my funeral ceremony also starts in my homeland. After my death, I also see my grave in my dream which is also in my country. My shroud is also in my country. My body and soul are both in my country. May my country accept my (Shpoonki's) dead body and my grave!

Oh people, can you interpret this dream for me!

The poet once again goes to his homeland in his dreams and wishes to see his country. He sees his death and life in his country and is not relaxed abroad and in his dreams, he has a dream to see his country.

Shpoon loves his country and frequently has dreams about his country whose great factor is travelling and being away from his country. He misses his country a lot and has the memories of his past. That is why he sees country in his dreams. It is said that some dreams are called symbolic dreams which cannot be interpreted by everyone. Even the dreamer cannot understand it. Kings of ancient time used to have dream interpreters for explaining dreams. The second type of dreams is called simple and easy dreams which do not need an interpretation. Shpoon's dreams are vivid and clear. He aspires for his country and misses his home and village.

\section{CONCLUSION}

Literature has a connection with psychology. Researching about dreams is a new section of Pashto Literature. Many scholars have presented their opinions about dreams, but in a written article, a research has been conducted based on Yong's Opinion and dreams of goodness and badness have been mentioned in it. Now it is clear that what type of dream Ustad Shpoon's selected poem has a connection with.

This poem of Ustad Shpoon is an association with dream and it is proven why people have dreams. What is the reason? Where does the dream come from? And what type of dream is that? 


\section{REFERENCES}

Herawi, S. R. (2014). Glimpses at anthropology of Zoroastrian and its Outcomes of training implications fifth year, the second number, $\mathrm{p} .2$

Kargar, M. A. (2016). Ghani in the Sand Palace and Give me A River of Light, Nangarhar: Hashimi Publishing Society, P.241

Shpoon, S. (2019). Prose Collection of Saadudeen Shpoon, published by Kanduz University, P.36.

Shpoon, S. (2020). Only one Shpoon. Jalalabad: Momand Publishing Organization. P44.

Shpoon, S. (2019). Poetic Collection. Balkh University, Advisor to the President in academic and social affairs, p. 39, 26, 46, 90, 91, 92.

Shpoon, S. (2019). Gems in Stones. (Ustad Shpoon Poetic Collection). By the efforts of Lal Pacha, azmon. Balkh University, Advisor to the President in academic and social affairs, p. 39.

Zadran, H. (2010). The World of Colors. Kabul: Danish publishing association. p. 20

\section{Copyrights}

Copyright for this article is retained by the author(s), with first publication rights granted to the journal. This is an open-access article distributed under the terms and conditions of the Creative Commons Attribution license (http://creativecommons.org/licenses/by/4.0) 